Cahiers $d u$ MONDE RUSSE

\section{Cahiers du monde russe}

Russie - Empire russe - Union soviétique et États indépendants

$56 / 2-3 \mid 2015$

Communiquer en URSS et en Europe socialiste

\title{
Stenography and the public sphere in modern Russia
}

La sténographie et le domaine public dans la Russie moderne

\section{Stephen Lovell}

\section{OpenEdition}

\section{Journals}

Electronic version

URL: http://journals.openedition.org/monderusse/8184

DOI: $10.4000 /$ monderusse. 8184

ISSN: $1777-5388$

\section{Publisher}

Éditions de l'EHESS

\section{Printed version}

Date of publication: 17 April 2015

Number of pages: $291-325$

ISBN: 978-2-7132-2476-8

ISSN: $1252-6576$

\section{Electronic reference}

Stephen Lovell, «Stenography and the public sphere in modern Russia », Cahiers du monde russe [Online], 56/2-3 | 2015, Online since 17 November 2019, Connection on 20 April 2019. URL : http:// journals.openedition.org/monderusse/8184; DOI : 10.4000/monderusse.8184

This text was automatically generated on 20 April 2019.

(c) École des hautes études en sciences sociales 


\title{
Stenography and the public sphere in modern Russia
}

\author{
La sténographie et le domaine public dans la Russie moderne
}

Stephen Lovell

1 Stenography brought about an unsung communications revolution in the modern world. For the first time ever human beings had a technology that allowed the written word to keep pace with speech and accurately record it. In the words of one of stenography's Russian pioneers, "how many works of genius, eloquent sermons, happy improvisations, clever and lively discussions have remained unknown, lost to posterity, due to the incapacity of ordinary writing to transfer them to paper." ${ }^{1}$ No wonder enthusiasts could promote stenography as a sign of human genius and progress. Its economic and civilizational benefits were almost too numerous to mention. Shorthand writing was not merely a means of recording public debate, but also a boon for students (who could save time when writing down lectures), for lawyers (who would be able to put their speeches in compressed note form on small pieces of paper), for investigators (who could record testimony), and for bureaucrats when taking down requests and complaints. The invention of stenography was "comparable to the invention of printing, which gave the opportunity for the rapid spread of education by accelerating the exchange of ideas." Stenography had enormous significance for an age of high-speed technologies such as steam, railway, telegraph and photography. How could "ordinary writing, which lags so far behind thought, behind the spoken word, fully satisfy the activities and demands of our age ?"3

\section{The Adoption of Stenography in Russia}

2 In the mid-nineteenth century, advocates for stenography could claim for their art an ancient pedigree: there was evidence of methods of accelerated writing (skoropis') among the Persians, Jews, Greeks and Romans. Most accounts agreed, however, that modern stenography started with the first attempts to revive this technique in the late sixteenth and seventeenth centuries, made further advances in the late eighteenth, but 
only really came to fruition in the nineteenth. The ste-nographic methods adopted and adapted in Russia mostly came from Germany : the main contenders were the systems of the Bavarian Franz Xaver Gabelsberger (1789-1849) and the Prussian Wilhelm Stolze (1798-1867).

3 The first native Russian work on stenography was published in 1820 by Modest Korf, then at the start of an illustrious administrative career ; it was followed by an anonymous work of 1844 that briefly summarized the systems in existence at that time while remaining uncommitted as to which system to recommend for the Russian language. ${ }^{5}$ By now, shorthand was in the peripheral vision of educated society. There might not yet be any active stenographers, but stenography was already a turn of phrase. In his 1835 historical novel Ledianoi dom, Ivan Lazhechnikov referred to an order by Biron (the notorious favourite of Empress Anna in the 1730s) being carried out "with the speed of a stenographer." In her account of the literary salons of the 1840s, E.A. Drashusova recalled the earnest German visitor Baron Haxthausen "constantly stenographing [ stenografirovavshii] anything interesting he heard." In his whimsical and insightful Staraia zapisnaia knizhka, Petr Viazemskii observed that a great deal of "literature," not to mention rumours, existed only in oral form : "Stenographers ought to be collecting it." Some contemporaries were even feeling their way towards stenography as a practice. When Nicholas I delivered a speech on serfdom to the State Council in March 1842, the very same Korf, now State Secretary and in his early forties, placed two men in the hall to scribble down as much as they had time for. Korf then refined their notes and added his own recollections of the speech. The result, in his words, was "not only the thoughts of the Emperor, but the very expressions he used, in so far as that was possible without the assistance of a stenographer."

4 Russia's adoption of stenography only began in earnest in the 1860s: this was quintessentially a technology of the reform era. It was the introduction of new public institutions - above all, the open courts and the zemstvos - that made the more systematic training of stenographers a matter of urgency. In a speech to launch a new course of stenography at Khar'kov University, Baron Nikolai Tornau hailed this development as an innovative piece of collaboration between university and zemstvo and as evidence of the increasing powers of engaged public opinion (obshchestvennost'). This new means of recording "live speech" (zhivoe slovo) was nothing less than a means of achieving the key goals of the reform age - publichnost' and glasnost'. If publichnost' were to be maintained, there had to be a way of transmitting speeches faithfully to the "public." Stenography would also hold orators to account. Speakers would now know that their words could be taken down accurately and subjected to criticism: "Stenography records all roughness and inaccuracy in speech with the same unpleasant directness as photography shows up facial imperfections." ${ }^{10}$

Khar'kov may have been the first university in the empire to launch a full course, but there were plenty of other educational initiatives in this field. Lectures were accompanied by a state-sponsored competition to find the best textbook on the subject and a lively jockeying for position among the adherents of the different systems. In Russia, as elsewhere, the profession very soon became feminized, as women took advantage of a still rare opportunity for advanced education and employment. Stenography was first used to record a public event in March 1860, when the historians Mikhail Pogodin and Nikolai Kostomarov conducted a celebrated debate on the question of the origins of Rus'. It was also adopted in some zemstvos and municipal dumas (particularly in the capital), though 
these bodies were soon reined in by the censorship when the authorities felt they had exceeded their powers. It was in the legal sphere that stenography made the greatest inroads in the reform era. Trial transcripts were an excellent way of providing endless gripping copy for newspapers. A well-known stenography teacher, Artobolevskii, tried to take advantage of this by launching his own newspaper, Glasnyi sud, in $1866 .{ }^{11}$ Although this venture was a financial failure, the main newspapers in the capitals - whether "boulevard" or highbrow - drew freely on stenographic reports, which had the further great virtue of avoiding censorship restrictions : all periodicals had the right to publish such transcripts in their legal section. ${ }^{12}$

6 Newspapers and publishers of the 1870 s seem to have stuck fairly confidently to the same principle. All the sensational trials of the time were covered in exhaustive detail, both in the newspapers and (sometimes) as separate book publications. In the early 1870s, for example, readers could find titillation in a graphic account of the sallow skoptsy; in the trial of Vera Dmitrieva for theft and "expulsion of the foetus"; and in the Miasnikov case of a forged will, where one of the defendants was picturesquely unhinged. ${ }^{13}$ The trial of the nechaevtsy in 1871 was recorded by a team of no fewer than seven stenographers. They worked in pairs, each one for 15-30 minutes at a time, and the transcript was published in Pravitel'stvennyi vestnik. ${ }^{14}$

7 Besides such frankly sensational offerings, stenographic transcripts offered readers the novelty of (purportedly) verbatim accounts of the speech of the common people from the peace courts. Their effect could also be heightened by journalists' accompanying commentary and reportage. As Louise McReynolds notes of the editorial policy of one boulevard newspaper, "Where Golos used stenographic recordings, Peterburgskii listok's editors vowed not to bore readers with these 'dry accounts.' Instead, they sent their 'own correspondents to court so that readers will get the effects of a living story."'15 Thanks in large part to the newspapers, certain lawyers acquired celebrity status. The orations of Fedor Plevako (who reportedly spoke from skeletal notes rather than a full text) had definite market value ; it was even worth Plevako's while to bring his own stenographer to court with him. ${ }^{16}$

8 The new technology, and its deployment in the press, also played its part in the expressive possibilities of Russian realism. ${ }^{17}$ In an article of 1861 , the critic Dmitrii Pisarev drew the parallel between photography and stenography : both these technologies were "objective" forms of depiction and hence excluded the authorial subjectivity that was the essence of literature..$^{18}$ Later writers would see here less of a contradiction. Speech of "stenographic" authenticity was a powerful new means of characterization. If Goncharov could refer in passing (and with an element of irony) to dialogue of "stenographic accuracy," ${ }^{19}$ Dostoevskii was the stenographer-novelist par excellence. Not only did he marry a stenographer and dictate his own works from The Gambler onwards, the illusion of verbatim fidelity gave many scenes in his fiction momentum and ethical voltage whether the famous philosophical dialogue between Ivan and Alesha in The Brothers Karamzov or the monologue of the abusive husband in "The Meek One" (the latter, the narrator invites us to imagine, is the only slightly edited work of an invisible stenographer). ${ }^{20}$ 


\section{The Rise of Political Oratory, 1881-1905}

9 After 1881, stenography had to labour under new restrictions, especially in the courtroom. Political and other sensitive trials were now off-limits. It was only by joining forces with two other journalists that Vladimir Korolenko was able to produce something close to a stenographic record of the notorious case of the Votiaks accused of human sacrifice. ${ }^{21}$ At the same time, however, stenography continued to bring more everyday legal business to the reading public. With the injection of foreign capital and the introduction of another new communication technology (the typewriter), it also extended its reach into the commercial sphere. ${ }^{22}$

Whether in the courts or in other venues, there was still plenty of public speaking going on. In the historian V.O. Kliuchevskii, the lawyer Plevako and N.A. Alekseev, the city's charismatic mayor in the second half of the 1880s, Moscow had its celebrities of the spoken word. ${ }^{23}$ The late nineteenth century saw the expansion of a market in self-help literature that offered budding ritores guidance on effective public speaking. ${ }^{24}$ Sergei Muromtsev, the future chairman of the First State Duma, was moved to comment acerbically on the number of occasions that gave people an excuse for holding forth. The death in 1885 of the actor Ivan Samarin was followed by a large funeral procession that set off from his dacha outside Moscow. When it reached Krasnye vorota, the cortege was stopped in its tracks by "some 'celebrated' magician of the word," who decided to deliver a eulogy on the spot - only then to repeat the trick at Samarin's grave. As Muromtsev noted sarcastically, “'events' are constantly generating demand for 'eloquence." The public celebration, complete with speeches, of the $25^{\text {th }}$ anniversary of the start of the career of a senior police official was the first time an anniversary of a member of the police service had been marked with such fanfare. Muromtsev likewise noted in 1886 the "colossal" growth in oratory in the Moscow duma, which made for an unfortunate contrast with the modest achievements of that body. Listening, moreover, was much less in evidence than talking. Deputies only really exerted themselves "at moments when they felt the need to make a general noise, to stir up the air with indistinct but loud exclamations. Such moments arrive frequently in our duma - whenever the majority feels the need to 'break off' a speaker it dislikes." Often they "did not exchange their thoughts or argue but simply bicker." 25

11 Yet the educated public had not lost faith in the political potential of public speech and its transcript on the printed page. That faith was only strengthened by the vigorous parliamentary politics taking place in the major European states (and reported in the Russian press) : in the post-1870 era, the British parliament had been joined by the French Chambre des députés and the German Reichstag as a venue for full-blooded debate. As a character in a contemporary novel by Aleksei Pisemskii notes, parliamentary orators might be "big rascals" but they did at least know how to speak; that was why their speeches came out well in transcripts. ${ }^{26}$

12 As before 1881, it was the zemstvo that was the litmus test of proto-parliamentary political discourse. It was all to easy to take a dismal view of the progress made since the golden age of the mid-1860s. Legislation of June 1867 had imposed restrictions both on speech within the assembly (to be policed by the chairman) and on the written record (which was subject to censorship by the governor, and to restrictions on distribution). Although enthusiasm had revived during debates on taxation in 1871, and again during 
the Russo-Turkish War, the zemstva were suffering closer police supervision since the "Going to the People" affair of the mid-1870s, and members were often afraid to state their opinions openly. The arbitrary power of the governor was never too far from their minds. ${ }^{27}$

Against this backdrop, stenography made speakers nervous even in a modest provincial zemstvo. In December 1886, the Simbirsk zemstvo assembly was informed that meetings would now be recorded in two different ways: as before, brief minutes (the zhurnal) would be compiled by the secretary of the assembly, but these would now be supplemented by a more detailed stenographic report. This news made several members of the assembly apprehensive. What would be the status of this new transcript - would it merely be an adjunct to the minutes, or would it be a "document" in its own right? Was the stenographer a mere clerical assistant to the secretary or an independent agent? How would the transcript be checked and approved by the assembly - would this not be too time-consuming? Would individual members have the right to strike out parts of their own speeches? (They would not - only the right to check the record.) The chair of the zemstvo board put into words the anxiety that many of his colleagues must have been feeling: "we are not orators, we've never studied this art, and it could happen to any of us that we let slip during a speech a word or turn of phrase that is not so rough as not to be heard out by the assembly but is not quite fitting for publication." The discussion dragged on, and in the end the chair of the assembly lost his patience and forced a conclusion of the debate ; at least members could be reassured that the all-important governor would be sent only the zhurnal, not the stenographic record. ${ }^{28}$

In due course, however, public speaking would take a more combative and political turn. An important catalyst was the famine of 1891-92, which brought a striking change in the dynamic between government and educated society. Provincial zemstvo meetings were back in the spotlight of publichnost'. One journalist from the capital arrived in Kazan just in time for an emergency zemstvo assembly in late September 1891. He was shocked by what the debates revealed of the zemstvo's weak grasp of the situation: it did not have the staff or the administrative clout to get to grips with the crisis that was unfolding. ${ }^{29}$ Among those who seized the opportunity for more engagé public speaking was the student activist and future leading Kadet V.A. Maklakov. The occasion was a large student meeting to discuss whether the proceeds from a benefit concert should be turned over to famine victims. In this unfamiliar setting - such gatherings were generally out of the question in Russia - Maklakov gave "the first big political speech in my life," his resolve strengthened by having read the speeches of Mirabeau. He even secured the initial agreement of Fedor Plevako - at that time "Russia's premier orator" - to deliver a speech at the concert, though later on the famous advocate declined the invitation. ${ }^{30}$

Later on in the 1890s, speakers were evidently beginning to press at the limits of the permissible in a variety of venues. Viktor Chernov encountered in Tambov what in Soviet times would have been called Aesopian speech at a lecture by V.V. Lesevich on Robinson Crusoe. ${ }^{31}$ In Nizhnii Novgorod, Pavel Miliukov enjoyed a large and excited audience for a series of lectures on the history of "social movements" in Russia - though these lectures cost him his post at Moscow University when a stenographic transcript reached the authorities. ${ }^{32}$ The relatively staid Moscow duma, where plain speaking was valued over high-flown rhetoric and where the seniority principle operated when deciding who got to speak, experienced a new style of oral disputation. The tedious "local Mirabeaus" with their unfounded pretensions were mitigated by the fine model of "parliamentary" 
eloquence provided by the already mentioned Muromtsev, scholar and lawyer, who a few years later was to take to the national stage in the State Duma. In the words of one prominent contemporary :

His fine, stately figure, his splendid voice, his often very animated words seized the attention of the Duma. Everyone listened to him - old deputies and young, those from the Arbat and those from the Rogozhskii district [i.e., both nobles and merchants]. Everyone enjoyed listening to Muromtsev, who so harmoniously combined fine and stately appearance with profundity of thought. He inculcated in the Moscow Duma the refined ways of the English parliament. ${ }^{33}$ not just in Moscow. In January 1899, Ivan Petrunkevich, later a star of the State Duma, gave an energetic speech to the Tver' zemstvo assembly in defence of the principle of glasnost'. For 33 years, he reminded his listeners, the Tver' zemstvo had been held in open session, but now the regional governor was demanding that the auditing commission be closed to outsiders. Glasnost' had been introduced, Petrunkevich argued, not just to indulge the vanity of orators; it was designed to help institutions work better. Objections were raised to this line of argument : even in liberal countries like England and France, equivalent committees did not hold their meetings in open session, and Tver' was the only provincial zemstvo to have kept the meetings open up to now. But S.V. de-Roberti backed Petrunkevich up : the analogy with Western Europe was false, as those countries had plenty of other arenas for public debate. And fundamentally: "If I am convinced of something, then I can say so freely in front of everyone and anywhere. Don't say things you can't say in front of everyone !" ${ }^{34}$

17 Tver' had a long record of public activism, but similar stirrings could be detected in the Orel zemstvo in the early 1900s, V.A. Obolenskii found that large landowners could be outspoken in their criticism of the government. At a debate on whether to petition for the abolition of classical education in middle schools, the discussion lasted for two days full of "perfectly parliamentary speeches." The hall was packed, and the speakers arguing against classical education received loud applause. In general, the liberals were the most fluent performers, while the reactionaries were unwilling to take the floor. ${ }^{35}$

the autumn of 1904, excitement grew in provincial capitals as newspapers carried reports of the bold oratory of the banquet campaign (even if the censorship vigilantly excised the word 'constitution'). ${ }^{36}$ In October 1904, a group of zemstvo deputies in Saratov complained that reports on meetings in the press had been severely cut and distorted. Three local papers replied to this complaint by pointing the finger at the censor :

all cuts and distortions in their speeches were made not by us and not by the editors but by the separate local censor, who considered it possible not only to strike out speeches in their entirety but even to insert his own words into official documents read out in the assembly and to replace expressions used by the deputies with his own words. ${ }^{37}$

Even in hitherto sleepy Simferopol, there was standing room only in the zemstvo assembly at the start of January 1905. But what finally turned the mood radical was a meeting of the local Agricultural Society on 10 January. The rumour spread that speeches would be made in favour of a constitution, and the hall of the city duma filled to bursting with people who would not previously have entered it - traders, workers, and various other representatives of "multifarious Simferopol democracy, craving to hear for the first time free public speech.” As Obolenskii recalled: 
In spite of us, the session had turned into a [political] meeting [miting]. It was impossible for us to speak standing in the thick crowd of people. Unaccustomed to the setting of a meeting, we were almost at a loss.

When Obolenskii was given the floor, he finally shed his inhibitions :

When my turn finally came and after clambering onto the table I saw the crowd of excited people with red, sweaty faces, when I sensed the expectant looks fixed on me from all sides, my head even started spinning from this unfamiliar situation. I have no talent as an orator, I am not even capable of the fluency you need when speaking in public. But in this unusual setting I felt as if intoxicated, and my tongue loosened.

Soon enough, Obolenskii uttered the previously taboo word "constitution," and then the meeting was presented with news of Bloody Sunday. ${ }^{38}$

The most politically salient use of public speaking in 1905 came in national gatherings of representatives of city and zemstvo assemblies. Zemstvo men shuttled back and forth between their provincial bases and Moscow, where heated discussions took place on reform projects that became more radical by the month. ${ }^{39}$ In mid-June 1905 was the first official congress of city representatives : a total of 126 people from 86 cities. Although this group of men had the reputation of being less outspoken than their zemstvo counterparts, being members of an urban oligarchy, they made bold speeches quite in tune with the radical moment. A stenographic transcript was published, but only in a small number of copies; the type was subsequently confiscated and destroyed. In 1905, a number of impressive zemtsy came to the fore, delivering speeches to a putatively national audience. They included the stern Petrunkevich, the fiery Fedor Rodichev, the sharp and meticulous Petr Geiden, and many others. ${ }^{40}$

\section{The Golden Age of Stenography : The Era of the State Duma}

21 These men would soon acquire a more stable platform in the State Duma. Yet the force of their words depended not just on the power of their oratory but also on the symbiotic relationship between the Duma and the press. Russia's parliamentary orators relied on the newspapers to bring their words to a wider public. ${ }^{41}$ As State Secretary E.V. Frish solemnly declared to members in the very first session of the Duma on 27 April 1906 :

Every step you take along the new path, every thought you express in your meetings, will immediately become the property of the entire people, which with the assistance of the press will follow vigilantly all your actions and undertakings.

A few days later, the firebrand Trudovik orator Aleksei Alad'in declared,

There are moments when speaking means taking upon oneself huge responsibility,

when speech is itself action. One such moment we are experiencing now.

As the Kadet V.D. Nabokov observed, the proactive orators of the Duma had nothing in common with earlier petitioners : "we have the moral right to be listened to, and we are fulfilling it." ${ }^{2}$ There was more than a suspicion that orators were speaking to the stenographer rather than to their colleagues in the chamber : "Some of them even openly admit that their duty is to express their opinions to the country over the heads of the people's representatives." ${ }^{43}$ The right-wing skandalist Vladimir Purishkevich admitted as much in a speech of March 1907: "knowing in advance that my words will not find support here, I speak over the heads of the Duma members and address myself to Russia." 44 

talking-shop. As one speaker noted early in the short life of the Second Duma, "we should remember that [...] we have come here not to chat, but to act [ne razgovory razgovarivat', a delo delat']." ${ }^{\prime 4}$ Long-winded debates in the Duma gave ample material for satirical commentators, for example the Novoe Vremia columnist who wrote under the pseudonym "Count Alexis Zhasminov." ${ }^{46}$ Yet, in a country undergoing its first experience of institutionalized political contestation, public talk was perhaps not such a trivial matter. As V.I.Ger'e replied after the Second Duma to the rhetorical question "What have we brought the country?": "Not so little: 4000 columns of published stenographic transcripts. ${ }^{.47}$ in Russian public life. No less an authority than Lev Tolstoi, ever quick to latch on to new labour-saving means of disseminating his thoughts, adopted it in his later years. From late 1907, Russia's greatest living writer dictated letters and even a few articles to his secretary N.N. Gusev, who had studied stenography in 1897. When sent a textbook on stenography, Tolstoi wrote back approvingly to the author: "I consider beneficial everything that helps to bring people together." ${ }^{\prime 48}$ Yet, before the creation of the State Duma, there were few stenographers with the suitable level of expertise. Moscow in the early 1900s had various stenography courses, but they mainly trained shorthand secretaries for the commercial sector (which required a speed of 50-60 words per minute rather than the 90-100 words desirable in a "parliamentary" stenographer). When the Duma was in session, stenographers were needed not only to sit in the chamber but also to work nights taking down decrees and reports by telephone from St Petersburg. All in all, the big newspapers of the post- 1905 era employed around 20 stenographers. This work paid well (120-150 rubles per month rather than the 50-70 that shorthand secretaries could expect), though it was demanding. Other assignments included zemstvo assemblies (three or four times a year for 6-10 days each time), lectures and occasional congresses. Even a congress of Old Believer communities employed stenographers, though the women who took on this task had to cover their heads in white scarves to disguise the nature of their activities. ${ }^{49}$

But it was the new Russian legislature that was the main spur for the consoli-dation of a Russian stenographic profession, which acquired its own Society in 1906. Even the mandarin State Council, now converted into the upper house, threw open its doors to stenographers. In March 1906, a competition was announced for stenographers to work at both the State Duma and the State Council (24 people for each). Seventy candidates took part, and forty passed ( 12 men, 28 women); the minimum required speed was the undemanding 80 words per minute. ${ }^{50}$ The Duma stenographers worked in pairs. The speeches were not corrected during transcribing; a six-man team of editors took those decisions. At the second competition in January 1907, 157 candidates presented themselves, and 29 passed. In February 1907, of the original 40, only 18 passed a further test. By 1910, 90 words per minute was the minimum acceptable speed. ${ }^{51}$

To begin with, women stenographers in the State Duma were appointed as assistants to the men, at a lower salary, but soon their status was made equal ; given the shortage of competent male stenographers, the women, with the support of their male colleagues, were able to assert their rights. By the Third Duma, the salary of a Duma stenographer had gone up from 75-100 rubles to 150 rubles. The women were required to dress in simple black attire and have modest hairstyles, and they were not permitted to talk to the 
deputies in the breaks between sessions. To begin with, a shift lasted 5 minutes, but it was soon found more effective for stenographers to work in shorter bursts of 2-2.5 minutes. Stenographers worked in pairs. After completing their shift in the chamber, they retreated to an adjoining room to write up their notes (with the assistance of a typist). The text then went to the Editorial department, which besides its director had a staff of six, who took turns to sit in on the debates so they could compare what they had heard with the texts the stenographers presented. All speakers were permitted to edit their own speeches, but not to make substantive changes. Stenographers, on the other hand, were required to deliver to the editors the unvarnished text, which sometimes made speakers blame them for the inadequacies of their own delivery. ${ }^{52}$

Stenographic transcripts were relayed by telephone and published in the next day's Moscow papers. They were accompanied by journalists' accounts of the impression made by various speakers. For example, the correspondent of Russkie vedomosti noted à propos the debate on the Duma's "Address to the Throne" that only Rodichev and I.V. Zhilkin had made contributions worth talking about. Zhilkin was "not one of those popular orators who win you over by their boldness and self-confidence. He has a large dose of sincere sentimentality. When he stands at the podium, his whole figure, his voice and movements, seem to say 'Take pity on us, poor suffering folk." ${ }^{53} \mathrm{~A}$ few days later, the same newspaper was merciless in describing the "quiet of the grave" that had met the speech of Ivan Goremykin, chairman of the Council of Ministers..$^{54}$ In the Second Duma, the journalists had even more fodder for engaging reportage, as right-wing orators (notably Purishkevich) did all they could to provoke the opposition. Conversely, Duma correspondents directed readers' attention away from speeches that had been drearily delivered. In a speech on 3 May 1907, the Chechen deputy El'darkhanov "spoke so quietly and monotonously that the deputies once again rose from their seats and set off in a long chain for the Catherine Hall." But the most tedious speech of all had been that of the Smolensk landowner Opochinin :

He stayed at the podium for a whole hour and a half, speaking in a quiet, monotonous voice ("Like a light autumn drizzle," as my neighbour in the journalists' box observed), drawing out his words, furnishing his speech with extended "ums."

While the El'darkhanov speech was at least published according to the stenographic transcript, Opochinin was granted only a two-line summary. ${ }^{55}$ Sometimes even renowned orators were a disappointment. The famous lawyer Plevako, who entered the Third Duma as an Octobrist deputy, fell flat :

Everyone was expecting from him a significant, sparkling and substantial speech, there were even rumours that he had written it out, but the general expectations were not fulfilled. His speech was colourful and all too smooth, it was trying to achieve external splendour but made a strange impression for its muddiness and contradictions. ${ }^{56}$

The transcripts of debates had a special status as an interface between the spoken and written word. The spokenness of Duma proceedings was vigilantly protected: according to the standing rules of the Duma (the Nakaz), it was forbidden to read out texts in the chamber rather than speaking unprompted, and the president intervened on several occasions to make sure this rule was observed. On 6 March 1907, for example, a fiery orator from Riga was interrupted by the question: "Mr Orator, are you reading or speaking ?"57 The same rule obtained in the upper house. In only the third session of the State Council, the scholar A.A. Shakhmatov encountered an objection on the ground that 
he had been reading out a prepared text, a practice that had not previously been allowed in this institution. The Vice-President upheld the point. The same issue came up on 27 June 1906, when I.G. Kamenskii, a forestry magnate from Perm', was ticked off for reading a speech (he claimed only to be looking at notes). On 4 July 1906, D.I. Bagalei sought an amendment to Nakaz on this point (to allow the reading out of specific documents that were necessary for elucidating the matter at hand). ${ }^{58}$ In January 1914, Aleksandr Kerenskii sought an amendment to the Nakaz of the Fourth Duma to permit deputies who did not speak Russian fluently to read out texts. This attempt to acknowledge the multi-ethnic nature of the Russian polity drew predictable outrage from Purishkevich, for whom it meant nothing less than "Babylon" (stolpotvorenie Vavilonskoe). But the proposal also met a more measured objection from the liberal Vasilii Maklakov. For Maklakov, the issue was not Russophone hegemony but rather how to ensure the authenticity of Duma speech: if non-Russian members were to have their speeches translated in advance for them to read out, they would willy-nilly be speaking someone else's words, not their own. The reason that the reading out of written texts was forbidden was to prevent the Duma from becoming "a place for declamation where people might recite the works of poets other than themselves." ${ }^{59}$

Another crucial principle of parliamentary life was that contributions to debate must be spoken in the chamber to have any status. In the State Council, F.D. Samarin proposed that members should have the right to express written disagreement with a decision of the Council, and to have these "separate opinions" (osobye mneniia) published as an appendix to the stenographic record. His idea met the objection that this would undermine the character and status of oral debates; people should have the courage to speak up with their objections. The vote duly went against Samarin. ${ }^{60}$

In light of this, it was especially important to ensure that the transcripts were an accurate record of what had actually been said in the chamber. According to rules approved in March 1907, members of the Duma had the right to correct the record of their speech either directly after the stenogram was completed or within two hours of the end of the sitting; changes were not to affect content, and if members did not come within the agreed time, reports would be published as they were ${ }^{61}$ The proposal in the Nakaz of the State Council was that speakers should get first sight of the transcript (before the Chairman) to check the record of what they had said. The finance expert V.I. Timiriazev spoke against this proposal on the grounds that

in this case it will be possible to change words for literary effect, but the whole purpose of stenographic reports is for people to know what was said here, even if it was inadequately expressed.

But the motion passed all the same, for a number of reasons : it would be too difficult to remember what you had said 10-15 days after the fact; it was in the general interest to get the transcripts out faster; and the speaker could provide the best check on the accuracy of the written record. ${ }^{62}$ Yet, while amendments were supposed to be limited to minor factual matters, it seems that the rules were routinely ignored by speakers from the government. For example, V.I.Gurko from the Ministry of Internal Affairs was reported by insiders to have completely overhauled a speech he gave in the Duma on the agrarian question; the changes were both stylistic and substantive. When D.I. Shakhovskoi and Muromtsev, respectively Secretary and President of the Duma, were informed of this, they just shrugged their shoulders. ${ }^{63}$ 

Purishkevich). ${ }^{65}$ inadvisable..$^{68}$

The stenographic transcripts allowed readers to acquaint themselves with a wide variety of communicative styles. The number of regular speakers might have been modest - a contemporary publication reported that in the Third Duma only 50 of 440 deputies gave speeches, and only 15 of these showed any real aptitude ${ }^{64}$ - but the rhetorical repertoire was much broader than in previous Russian political discourse. At one extreme was the gentlemanly Muromtsev, chairman of the First Duma. As Obolenskii noted, nowhere, under no circumstances did he forget his elevated position. He developed for himself manners and gestures that, according to his artistic intuition, corresponded to his presidential figure. It seemed to me that he even ate and slept not like everyone else, but "in a chairmanlike fashion."

There were also eloquent old-school zemstvo orators such as Petrunkevich, Rodichev and Geiden, whose stammer did not prevent him from holding the audience's attention. There were populist politicians such as Alad'in, who made a pitch for the peasant constituency. There were bluff conservative landowners and shrill right-wing orators (Shul'gin,

Some of the orators with pre-1905 pedigree did not seem quite so effective in the cold light of stenographic publichnost'. To some observers, Muromtsev came close to being mannered and narcissistic. The celebrity orator Plevako did not manage successfully the transition from courtroom to debating chamber. ${ }^{66}$ Deputies who kept to old-fashioned notions of rhetorical elegance also now had to compete with speakers who paid little if any attention to such niceties. The latter notably included peasant and non-Russian deputies, who regularly apologized for their poor command of the language and their inability to match up to the rhetorical heights of a Rodichev or a Petrunkevich ${ }^{67}$ But such modesty often rang insincere : inelegant expression was coming to connote authenticity. Falsely self-deprecating orators could be found even in the State Council. In his contribution to the debate on the amnesty on 4 May 1906, Prince Kasatkin-Rostovskii presented himself as a "modest provincial" who could hardly compete for eloquence with the outstanding scholar and statesman who had preceded him (Lappo-Danilevskii). He asked his audience to listen "not to how I speak, but to what I say." His 30 years in the countryside ( 25 of them as marshal of the nobility) had convinced him that the peasantry needed proof that the government was in charge ; for this reason an amnesty was highly

From the beginning, some Duma orators were pushing at the limits of propriety. A famous case was Rodichev's reference in November 1907 to the hangman's noose as a "Stolypin necktie," which was apparently uttered in the heat of the moment and led to Rodichev's expulsion from the chamber for 15 sessions. Rodichev did at least apologize to Stolypin soon after the fact, but other offenders were less contrite. Seven months earlier, during a session of the Second Duma, A.G. Zurabov had delivered a speech that loyalist members of the Duma considered had insulted the army. Not only was Zurabov censured by the President of the Duma, his speech was not published. The decision to censor drew a protest headed by Iraklii Tsereteli and signed by 31 deputies :

The attitude taken by the President of the State Duma in the last few sittings, and especially in the past two days, has convinced us that he is systematically abusing his right to intervene in debates and silence speakers. ${ }^{69}$

Complaints of censorship reached a crescendo over the working life of the final, Fourth Duma, which became even more theatrical with the arrival of the tiny Bolshevik fraction. ${ }^{70}$ As early as January 1914, some members argued that the Nakaz should be amended to 
stipulate the wide dissemination of stenographic transcripts, which provided a "completely objective" record of proceedings; the newspapers were publishing no more than extracts from the debates, while the official newspaper Rossiia had just ceased publishing the transcripts as free supplements. ${ }^{71}$ In late 1916, speeches by the opposition were being systematically excised from press reports on Duma debates (though other ways were found to disseminate these speeches among the population)..$^{72}$ In November 1916, M.S. Adzhemov, a Kadet deputy representing the region of the Don Cossack Host, commented à propos the excisions from the version for the press :

The Duma has been cut off from the country. You, gentlemen, are shut away in this hall, in this old Potemkin palace, closed off, shut away, and you are told : shout all you like, talk, get indignant, Russia won't get to know a single word all the same.

M.I. Skobelev, a Menshevik representing the Russian population of the Transcaucasus, raged that the "tormented, insulted and bleeding country" had expected the Duma to provide the whole truth, but instead it was getting "blank spots" which only served to excite further rumours. The press needed to do more to infuse the dry stenographic reports with life. A month later, Skobelev would poke fun at Adzhemov, who purportedly wrote out his speeches a whole week in advance. That kind of leisurely working practice was out of the question for members of the overworked social democratic fraction. ${ }^{73}$

By now, measured eloquence was emphatically out of fashion. Kerenskii had pushed himself to the fore as one of the most active orators in the Fourth Duma, and by late 1916 his speech (even as represented in the official stenographic transcript) was explosive and elliptical. One can almost hear the chokes of indignation in passages such as the following: "there is just one thing left for us to say, to say, that we are silent because our throat has been rammed shut, because the country is being abused ... and because they don't want to give the people their rights." ${ }^{\prime 4}$ In the words of one deputy consistently hostile to the rhetorical extremes of the Fourth Duma, Kerenskii "spewed out words as if from a machine gun and drenched the stenographers sitting below in a fountain of his poisonous saliva." ${ }^{75}$ Nikolai Chkheidze was another orator who was by now doing much to reshape the norms of political communication in Russia. In a speech of 16 December 1916, he made a virtue of his non-native Russian :

I should tell you, that despite the fact that I am speaking this broken Russian, while [V.I.] Stempkovskii uses pure literary language, I should say, that both here and in the country people listen to me with no less attention than Mr. Stempkovskii, who speaks such good Russian. That's the first point, and the second is that our whole government also speaks pure Russian and that doesn't stop it being a traitor. ${ }^{76}$

\section{Revolutionary Talk and the Birth of the Soviet Stenographic Profession}

The eventual successor regime to the State Duma, while it might decry that body's ineffectual loquacity, did plenty of talking of its own and wanted it recorded. In the words of Georgii Chicherin in 1923,

Every factory meeting, every village assembly, every session of a local party cell or a local committee of a particular profession is an event in the history of the development of that social unit, an event that should be fixed and recorded. ${ }^{77}$ April 1917 saw the creation of a stenographers' society (Professional'noe obshchestvo stenografistok i stenografov). The All-Russian Executive Committee (VTsIK) organized a 
permanent staff of stenographers in 1919. By 1924 all Sovnarkom debates were recorded. ${ }^{78}$ The Supreme Soviet had 26-28 stenographers, and a session of one of the houses was recorded by 13-14 people in 10-minute shifts. In 1925, not unreasonably given the pressures of working in the early Soviet state apparatus, stenography was recognized as a "harmful profession" (vrednaia professiia). ${ }^{79}$

The growth of new political assemblies in 1917 placed enormous new demands on the stenographic profession. Before the revolution there had been no more than ten major congresses per year in Moscow ; in 1917 and afterwards, there could be as many as 20 per month. The political stakes were high: delegates had a great deal to say, often at high speed in poor acoustic conditions, yet it all had to be taken down. In 1917, Soviet Russia had only 100 registered stenographers, and even in 1923 the figure was only 200. Of those 100 , only 37 had the highest qualification necessary for "parliamentary" work. During the Civil War period, it sometimes happened that there was simply no stenographer available to record some important gathering, and stenographers were often in the position of having to work solo and for much longer shifts than was desirable. ${ }^{80}$

Stenographers would later recall the huge pressure under which they worked. In one case, a session of a trade union congress got to midnight and there were still sixty delegates who had signed up to speak. The stenographers were given permission to leave the hall and work on writing up their notes, returning only for the final statements. But then a member of the presidium stormed in and accused them of sabotage for abandoning their post. On another occasion, stenographers were threatened with sanctions from the Cheka if they failed to turn up at short notice to record a meeting of a fraction at a trade union plenum. ${ }^{81}$

Yet, for all the strains of the revolutionary period, many leading Bolsheviks seem to have had a close working relationship with their stenographers, fully recognizing their dependence on this communication technology. Trotskii took his own group of stenographers for the negotiations at Brest-Litovsk. ${ }^{82}$ According to various (no doubt embellished) memoirs published in Voprosy stenografii, Lenin appreciated the work that stenographers did and on one occasion stepped in to make sure they were provided with telephones. The stenographers, for their part, admired his ability to communicate with different audiences, though were mildly exasperated by his "German" syntax and his habit of striding about the stage (in vain did they try to use their table as a barricade to prevent him wandering out of earshot). ${ }^{83}$

In the mid-1920s, various living Bolsheviks expressed their appreciation of stenography in writing. In Chicherin's words, the stenographer was "our closest and most faithful collaborator, to whom we confide all our thoughts." ${ }^{84}$ For Mikhail Arzhanov, recalling his work organizing transport during the civil war, “I didn't do a single day's work without stenographers and only with their help was able to get through work for which there were not enough hours in the day." Stenographers had not only recorded his words with "photographic accuracy," they had even finished off thoughts that he had left incomplete. As Anatolii Lunacharskii observed, stenography had become "one of those connective tissues that embraces all elements of public [obshchestvennoi] life and without which it cannot be imagined." 85

Even before the civil war was over, the new Soviet state was making efforts to train up a post-Duma cohort of stenographers. There were about 50 applications for stenography courses organized by the union of office workers in 1920. About three-quarters came 
from women; the ages of applicants ranged from 16 to mid-30s, and secretaries and typists were the main occupations represented ${ }^{86}$ In 1921, 47 people were enrolled on these courses, though attendance was well under 50 per cent. ${ }^{87}$ These, of course, were very modest numbers. By 1924, however, stenographers were developing a distinct professional identity, and there was talk of overcoming the "appalling charlatanism" of much stenographic practice in the provinces by providing more organized central training. ${ }^{88}$ In March 1925, Soviet stenographers had their first all-union conference in Moscow, attended by 98 delegates with voting rights from many parts of the RSFSR as well as Ukraine, Belorussia and Azerbaijan. The main purpose of this event was to generate esprit de corps in a profession that was thinly spread and lacking a sense of common identity. Although the number of registered stenographers in the country had by then risen to 700, this was still very few, and only Moscow and Leningrad had more than a dozen or two stenographers. Moreover, practitioners of the craft were more likely to identify with the institution where they worked than with their fellow stenographers. ${ }^{89}$ By 1930 the number of registered stenographers had tripled relative to 1925 ; there were more than 600 in Moscow alone, and most of these had stable jobs in Soviet institutions. ${ }^{90}$ A veteran of the "Bureau of Congress Stenographers" later recalled the very heavy workload of the early 1930s. Whether it was meetings in Gosplan, Party purge hearings, lectures in the Communist Academy, endless trade union assemblies, or full-blown congresses, the stenographers of the 1930s - a combination of 'old' intelligentsia women, upwardly mobile wives of the Soviet professional classes, and recent (largely Jewish) migrants to the city - had their hands full. Especially demanding was so-called 'parliamentary' work, when the stenographers had to write up their notes on the spot; for such jobs four women had to work in sequence in order to keep pace, and a fast-talking orator made the task even more demanding. In the Soviet 1930s, given the potential for politically sensitive error, this was nerve-wracking work, even if some assignments were considered relatively easy. The less scrupulous stenographers tried to get themselves assigned to trade union events, where there were long breaks between sessions and where the language was simple, clichéd, and predictable. ${ }^{91}$

The dignity of the Soviet stenographic profession was asserted not only internally but also internationally. In 1927, the USSR for the first time sent a delegate to the International Congress of Stenographers (held that year in Brussels); he proudly reported on the Soviet system of social insurance for stenographers. ${ }^{92} \mathrm{~A}$ few years earlier, a prominent Soviet stenographer was given a tour of the facilities for her counterparts in the British Houses of Parliament. She commented critically on the awful working conditions and noted that British parliamentary stenographers were older than their Soviet counterparts (rarely below 35), exclusively male, and without specific stenographic training. Rather, they had backgrounds in journalism; a smooth text was valued over word-for-word accuracy. The chief stenographer effectively worked as a "newspaper editor," i.e. as a censor..$^{93}$

Given the demand for their services, it was understandable that some shorthand practitioners in the early Soviet period voiced extravagant ambitions for stenography: that it should be made a compulsory subject in tertiary education institutions for white-collar professions, and that it was a skill uniquely well-suited for the high-speed modern era. ${ }^{94}$ As a rhetorically overcharged editorial declared in the very first issue of Voprosy stenografii, stenography was "'the best means of instantly recording living speech 
and thought," "winged writing, aeroplanography" (krylatoe pis'mo, aeroplanopis') : "if in the centuries to come humanity continues to write, then it will write stenographically." 95

In the future, a machine would be invented to take the place of stenographers, but for the time being shorthand was a cutting-edge technology: "in the previous era books were written by authors, but now a significant number of books are taken down by stenography." ${ }^{96}$ As Lev Trotskii commented, stenography imposed a machine-like work rhythm :

When two people are sawing wood, then they have to work rhythmically ; when you learn how to do this, it makes the work far easier ; the same with a stenogram : your thinking gets disciplined, it works more rhythmically in tandem with the stenographer's pencil. ${ }^{97}$

51 But the Soviet stenographic profession was by no means without internal conflict. There were two overlapping sources of tension : first, the relationship between highly qualified "congress" stenographers and those capable only of lower speeds; second, that between stenographers employed permanently by institutions (who were mainly what we would call shorthand typists) and freelance operators. Resentful colleagues considered freelance parliamentary stenographers to be "tourists" who travelled around taking all the most lucrative work (this at a time of low pay and underemployment). ${ }^{98}$ Parliamentary stenographers periodically complained of suffering discrimination from labour exchanges, which were inclined to consider them a privileged "caste" earning vast sums while their colleagues went hungry. ${ }^{99}$ Earnings and career prospects varied enormously from one part of the country to another. In Rostov on Don, for example, 26 stenographers had salaried employment and earned a healthy 80-120 roubles per month ; many of them, moreover, were able to supplement their earnings with freelance work. In Krasnodar, by contrast, salaries did not exceed 75 roubles, rates for freelance work were correspondingly low, and there was much unemployment. ${ }^{100}$ Whichever category stenographers belonged to, they sometimes had to fight for their professional dignity. Many employers failed to understand that a stenographer could not be expected to sit chained to a desk from nine to six, or that six hours per week of meetings to transcribe was in fact a heavy norm (given that one hour of speech normally required five hours of transcribing). ${ }^{101}$ Physical exhaustion was common, and there was much discussion, whether at meetings of the professional union or in the journal Voprosy stenografii, of what is now called repetitive strain injury. ${ }^{102}$

There was also a more fundamental reason for unease. For all the rhetorical insistence on the birth of a "Soviet" stenographic profession, the awkward fact was that many stenographers active in the 1920s had earned their stripes in the State Duma. It was largely the same group of elite Duma stenographers that later worked in the "Pre-parliament" of 1917, the commission for preparing the Constitu-ent Assembly, and the short-lived Constituent Assembly itself. These women and men were also involved in recording the big congresses of soviets in 1917. After the October Revolution, they remained active, even if they were not tied to a single political body as in the Duma era. ${ }^{103}$ The very term "parliamentary stenographer" was a constant reminder of this undesirable heritage. As one speaker commented at a meeting of union representatives and other interested parties in September 1924, "I would suggest abolishing the word 'parliamentary.' It keeps raising objections. [We should instead speak of] simply training stenographers of higher qualification." ${ }^{104}$ In due course the term was indeed replaced by the more neutral "congress stenographer" ( $s$ "ezdovskii stenograf). 

fundamental ambiguity of the stenographer's craft. On the one hand, stenographers were machines for reproducing the spoken word. On the other hand, they were eminently human and could not help being affected by what they heard in what were sometimes the upper echelons of power in Bolshevik Russia. ${ }^{110}$ Moreover, theirs was an art of interpretation: not only did stenographers have to exercise their judgment when they came to decipher their shorthand symbols and convert speech into written text, they even had room for creativity in the ways they graphically represented the words they were recording. It was an increasing source of annoyance to administrators, but a fundamental fact about the profession, that stenographers were divided by the methods they used. The systems of Stolze and Gabelsberger still had their devotees, and neither group had much incentive to work towards a "unified" system that would render obsolete much of their training. In the 1920s, Soviet stenographers even found themselves wondering whether they were practising an art or a science. One observer-participant in 1924 had no time for this discussion :

we need to throw out the notion that stenography is an art, that's an old debate.

Stenography is not an art but a science, the most ordinary kind of science, which in the future will replace conventional writing. ${ }^{111}$

Even so, the question evidently continued to exercise some of her colleagues. ${ }^{112}$ A speaker at the first stenographers' conference went so far as to cite Lombroso's notion that genius and madness were almost the same thing: "When we observe outstanding stenographers, we can also say that they are not entirely normal people." ${ }^{113}$ 

stenographers redundant, but in the end it spurred stenographers to assert their dignity as something more than machines. Admittedly, many of the objections to the new machines were practical - they were too expensive. As one contributor argued, it was a much better use of scarce resources to buy a couple of hundred tractors than to spend thousands of roubles on importing stenographic machines. ${ }^{114}$ An "automatic stenographer" designed by V.I. Kovalenkov, head of the Leningrad Electrotechnical Experimental Laboratory, was effectively a tape recorder that used cinema film. The intention was that this would cut out the stenographers, as the tape could be slowed down to the speed of a typist. But there was some scepticism that this machine would prove cheaper than existing arrangements. For one thing, the services of a technician would be required, but the main cost would be the tape and the chemicals required to develop it : one hour's worth of transcription would cost 250 roubles, or 17 times what it would cost to hire a human stenographer. ${ }^{115}$

A more fundamental drawback of these precursors of the dictaphone was that they could not take editing decisions. As representatives of the central stenographers' union wrote in 1928 in response to a query from a member about how to view the new technology, the dictaphone was unsuitable for adoption not only because it was still unreliable and difficult to use. The bigger problem was that the transcripts of most speeches needed extensive correction and editing, and the combination of tape and typist was not capable of doing this. ${ }^{116}$

The precise character of stenographic editing was itself a subject of much debate in the 1920s. Stenographers had long found it hard to strike the right balance : if they gave an absolutely faithful record of what had been said, it looked ugly; if they edited the text, speakers were liable to accuse them of taking liberties. ${ }^{117}$ There were different views on how interventionist a stenographer should be : should she correct basic errors, carry out "literary" editing of style, or vary the approach depending on the speaker and the occasion? Many meetings, especially in the provinces, included speakers of modest education, and their words would make a strange and unfavourable impression if they were not significantly edited. ${ }^{118}$ One stenographer from Yaroslavl argued that it was only a matter of common sense : in the provinces, there were not enough good speakers to make a "photographic" style of stenography worthwhile. If stenographers did not smooth out the rough edges of speeches, the authority of their profession would suffer. ${ }^{119}$ In his speech at the $1^{\text {st }}$ all-union conference of stenographers, Mikhail Kalinin lent his support to this view :

You hear me now and understand perfectly what I am saying, but if you wrote down what I was saying word for word, you would get nonsense, because speech is one thing and a stenographic transcript quite another. ${ }^{120}$

As a "regime of economy" was announced for Soviet institutions, minutes (protokoly) as opposed to full stenographic transcripts gained more advocates. A protokol cost only half as much as a stenogramma, and it was quite wrong to consider it - as many died-in-the-wool stenographers did - a "profanation" of the stenographer's art. Rather, it was a "condensed, well compressed stenogram from which all the water has been squeezed out." Writing minutes was no easier than compiling a stenographic transcript : it required a good deal of experience and skill. ${ }^{121}$ As "industrial" efficiency became all the rage at the end of the 1920s, the main professional journal published more articles in support of the protokol. It was not true, one contributor argued, that minutes should be 
eschewed just because speakers preferred to see a full transcript of what they had said: "Orators can demand all they like, but we have to reckon with the requirements of the administration." As another short article noted, minutes rather than a full transcript obviously made best practical sense in most cases. If stenographers objected, this was because they were reluctant to learn a new skill. ${ }^{122}$

Yet there remained many occasions in Soviet life that required a full stenographic transcript, and it was still a matter of dispute what degree of editing was legitimate. The content was sometimes too specialized for stenographers to edit with confidence. Another problem was that they risked flattening out the distinctive features of different speakers. What, for example, if the uneducated speech of a peasant or worker was transformed into flawless literary Russian in the written record ? ${ }^{123}$ As one contributor noted, the common notion that the stenographer 'photographed' speech was misleading. The transcript was not a machine-like reproduction but rather a recreation. A better analogy was film:

stenography is cinematography of speech and of the speaker himself where you are only the cameraman turning the handle but are also - alas! - responsible for providing an interesting story and elegant poses and everything else. ${ }^{124}$

\section{Stenography and the Bolshevik Public Sphere}

In early Soviet Russia, these were matters not just of professional practice but also of political import. Stenographic records became a significant political tool in the period of "collective leadership" after the death of Lenin. After June 1923 some Politburo meetings were stenographed, and the transcripts might then be circulated (on terms of strict confidentiality) to the wider elite of provincial party secretaries and leading comrades in various other organizations. Only a small proportion of meetings were recorded in this way; the general trend in the 1920s-30s was for the inner circle to become more secretive, and in the late 1930s stenographic transcripts were discontinued entirely for the Politburo (to resume after 1953). But for a crucial phase in the mid-1920s they played a significant role. In March 1926, for example, Stalin accused Kamenev of playing to the stenogram, while Dzerzhinskii in June 1926 even declared : "I consider it a crime that we have stenograms, that we are speaking for the documents." As these examples suggest, Politburo members were acutely conscious of the fact of having their words recorded and took some trouble over editing the transcript before its wider dissemination. The decision to have a meeting stenographed was always taken for a reason - usually to send out policy signals or admonitions from the inner circle to its plenipotentiaries beyond Moscow. ${ }^{125}$

Politburo meetings were one thing; Central Committee plenums quite another. The latter were conceived as a forum for Bolshevik "democracy" - as a means for a political elite broader than the inner circle to hammer out political issues, and also a means of transmitting their deliberations to a wider public of party functionaries. The means of transmission was the stenographic transcript. Leading Bolsheviks promoted the notion that plenums were honest and uncensored events where speakers did not shrink from articulating unpleasant truths. As Stalin said in an unscheduled speech at the July 1928 plenum, if the language used was sometimes harsh, it was also straightforward and accurate : 
Some people think that you shouldn't speak the whole truth at a Central Committee plenum. But I think that we are obliged to speak the whole truth at a plenum of the Central Committee of our party. We shouldn't forget that a Central Committee plenum is not a peasant meeting [miting]. Of course, the words "supertax" [ sverkhnalog], "something resembling tribute" are unpleasant words, because they slap you in the face [b'iut $v$ nos]. But, first of all, words aren't the point. Second, these words fully correspond to reality. ${ }^{126}$

a sense among the participants that the stenographic transcript was a documentary record of events that constituted a higher authority than the word of any single speaker, however powerful. On three separate occasions, the statistician V.V. Osinskii, later to be executed for his role in the ill-fated 1937 census, objected that his line of argument had been misrepresented by Stalin, in two of these cases referring listeners to the stenogram. For example :

Osinskii : I am just reading that place in the transcript.

Stalin: So much the better, but I seemed to hear something different [mne poslyshalos' nechto drugoe]. ${ }^{130}$

67 In many other places, moreover, the proceedings do not read like the carefully vetted transcript of authoritative Bolshevik discourse. If Stalin's speeches were amended to give the impression of conciseness and authority, Mikhail Kalinin took the opposite approach. In July 1928, Kalinin had his back to the wall as a member of the leadership known to be "soft" on the peasant question. At the plenum, he tried to stick to the line of moderation - but did this only by adopting the persona of Bolshevik iurodivyi (holy fool). Whereas other speakers were concerned to cram their allotted time with examples, arguments and rebuttals of counter-arguments, Kalinin positively welcomed opportunities for digression and frivolous asides. He got involved in a joky dialogue about the "learned" phrase "Scylla and Charybdis." ${ }^{131} \mathrm{He}$ constantly wandered off topic. He played to the gallery. 
When asked directly by an exasperated Nikolai Skrypnik whether he supported religious communes, he replied in mock-indignation : "I'm amazed - as if any of the orators here have spoken more directly than I have." 132 At this point the stenogram records "Laughter" - and we can probably assume that this was not the canned Stalinist laughter of the 1930s but genuine hilarity.

Even more strikingly, Kalinin repeatedly drew attention to the ways in which the transcript did not accurately reflect the sense of speakers' words. A written text wrenched words out of the context of speaker-listener interaction that gave them meaning. In a tangled explanation of his attitude to the kulak, he forced the stenographers to resort to scare quotes: "The question is: how to support the kulak? You can support and 'support'. You can 'support' the kulak in a Marxist way." Unsurprisingly, this statement was followed by a "burst of laughter." A little later, in one of his more striking digressions, Kalinin reminded his colleagues that Lenin, when angered by someone, would often say "Shoot him !" (Rasstreliaite!). But, of course (!), the founding father had not meant this literally. When ticked off by Emel'ian Iaroslavskii that the plenum would be read by the whole party membership and that he should watch his words, Kalinin said he would take care when correcting his text for publication but that a speech was something different : "I'll need to think over the stenogram very strictly, but when I deliver a speech, I want to impress my thoughts on the consciousness of people as fully as I can." At the November 1928 plenum, Kalinin again asserted that, whatever the imperfections of his speeches in their written form, he was unmatched in his ability to connect with an audience. When he struggled to get back to the point after yet another digression, he stated: "My strength relative to other authors is that people listen to me attentively ... For that reason, comrades, it's not the stenographers but the audience who remind me what I was talking about." Naturally, the reaction to this was more "laughter." 133

At the November 1928 plenum, the oppositionist M.I. Frumkin also used laughter in an attempt to disarm the audience :

I realize that Comrade Stalin had to choose Frumkin as a punchbag [...] I mustn't, of course, be offended. If it's necessary in the interests of the party, then I can reconcile myself to this.

But Frumkin went on to refer to the stenogram as a means of setting the record straight :

I would not have asked for the floor if I had been confident that my "letter" would be added to the stenogram, if it would be possible [for readers] to compare what I said in my "letter" with what comrade Stalin has said about me. ${ }^{134}$

Yet stenograms were themselves vulnerable to misuse. Another Bolshevik on the defensive, A.M. Lezhava, objected to V.V. Lominadze's misleading quotations from the transcript of a speech he had given in Gosplan (but not subsequently seen). What followed was perhaps the most explosive thing said at the entire plenum :

If you yanked phrases out of Stalin's speech yesterday, you could cobble together any deviation you like ... From his speech you could make a Russian nationalist, and a Right deviationist, and whatever you like..$^{135}$

It almost goes without saying that this passage was removed from the version of the transcript circulated to party members. ${ }^{136}$

71 The April 1929 plenum, at which Bukharin was routed by Stalin, brought a rhetorical point of no return. For one thing, oppositionists were heckled incessantly in a way that leading Bolsheviks had not previously had to endure. Bukharin poignantly compared his predicament with that of a convicted prisoner in tsarist Russia enduring the ceremony of 
"civil execution." ${ }^{137}$ Another novelty was the extent of excisions in the published version (which notably included Stalin's response to the reactions of the oppositionists, which was evidently not sufficiently condemnatory) and the secrecy surrounding Stalin's main speech, a version of which was only published just before his death, in volume 12 of his collected works. That speech itself was unprecedentedly long and peremptory in its tone ; this was already the dictator speaking. ${ }^{138}$ In addition to his other sources of power, Stalin now had a grip on political communication: he got to decide what version of which transcript came to light, and under what circumstances. It was symptomatic that the death blows to Bukharin's political legitimacy in 1929 were two written versions of spoken encounters: the first was Kamenev's account of a meeting with Bukharin in summer 1928 where the "Rightist" had in desperation reached out for support to a defeated "Leftist"; the second was the stenographic transcript of a speech in September 1929 by a repentant Rightist from the Industrial Academy, which clinched the matter of Bukharin's expulsion from the Politburo. ${ }^{139}$

Soon enough, stenography was playing its part in what Jürgen Habermas termed the "plebiscitary-acclamatory" public sphere of modern dictatorship. ${ }^{140}$ In the 1930s, the transcripts of political events became largely divorced from the original speech situations. As Natalia Skradol observes in her study of Stalinist laughter, it is impossible to know what degree of collective mirth occurred in actual fact. The important thing is that the stenographic records of it, designed now for publication in the Soviet press, were a "communicative act" of a new kind. They represented the power of the political leader to control the audience's reactions, the rhetorical unity of leaders and led; they "affirmed society's ideological cohesion [...] without making necessary the audience's verbal involvement." 141

Yet acclamation of the Leader was not the only function of this Stalinist public sphere. No less important was its role in enforcing surveillance. As the original "self-criticism" campaign of the late 1920s mutated into witch hunts and forced recantation, party meetings became a means of turning the entire Soviet public into a "collective hostage." ${ }^{142}$ This public sphere was profoundly disempowering for its participants, whose words as rendered in the "raw" stenographic transcript - would be at the mercy of their first readers in the party-state apparatus ; if anyone failed to keep to the script, their speech would in any case be rewritten in the version of the text that reached the reading public in the newspapers. The clearest demonstration of the point came in Stalin's final reckoning with Bukharin in the show trial of March 1938. Not only did Stalin have a cable laid so that he could listen to proceedings in the comfort of the Kremlin, he also personally edited for publication the transcript that he received from the Military Collegium of the Supreme Court. Although the defendants had on the whole kept well to the script rehearsed with them by their NKVD minders, the text was nonetheless amended to remove any lingering ambiguity and to omit any embarrassing information that had been divulged in passing. The dictator was in a hurry : the death sentences were carried out on the night of 14-15 March, but already on 28 March the full text of the transcript was approved for publication. Here was the rhetorical culmination of prewar Stalinism : a grotesquely extended exercise in self-incrimination serving as the ultimate act of acclamation. ${ }^{143}$ 


\section{Conclusion : The Age of Stenography, 1860-1940}

74 Of course, stenography had never provided an exhaustively faithful record of public speaking events. The eminent lawyer A.F. Koni complained in 1914 that people were too ready to judge jury trials by what they read in the papers : stenographers didn't always catch what had been said or grasp the sense of it. ${ }^{144}$ As Viktor Chernov noted poignantly of his own violently heckled speech at the doomed Constituent Assembly in January 1918, "Whoever reads the stenographic transcript of this session will not have even a remote idea of what was going on in actual fact." ${ }^{145}$

75 All the same, stenography left a powerful mark on Russian public culture from the middle of the nineteenth century to the middle of the twentieth. It was the fundamental communications technology for the era of political participation that began in stuttering fashion in the 1860s, gathered pace in the early twentieth century, and reached its grotesque apogee in rituals of Stalinist culture such as the congress or the purge meeting. Until the advent of user-friendly recording technology (the magnitofon) in the 1940s, it had no serious competition as a documentary record of public speech, and it thus played a formative role in the development of modern Russian political rhetoric. Radio, by contrast, could broadcast the spoken word more effectively than stenography, but it could not preserve it for dissemination after the moment it was uttered. ${ }^{146}$ Stenography also differed from radio in being a technology that straddled the tsarist and Soviet periods, which made it a particularly sensitive barometer of rhetorical evolution, adaptation and (in the long run) transformation. By analysing how speech was turned into writing, we can see the tension between absolutist and bourgeois public spheres in the late imperial era; between bourgeois and plebeian forms of rhetoric in the revolutionary period; and between plebeian, acclamatory and incriminatory dimensions of public speech in the Stalin era. ${ }^{147}$ A more ambitious treatment of the subject might go on to consider the difficult renegotiation of Stalinist rhetorical norms in the Khrushchev era as well as the creation of multiple socialist publics at the level of institutions, professions and informal or voluntary groups. ${ }^{148}$

In stenography we find an ambiguity characteristic of the whole era of Russian modernity for which it provided a transcript. On the one hand, stenography had liberating and democratizing implications. From the 1860s onwards, Russians had ways of talking back at the diktat of written ukazy. Stenography threw open the written record to people who were previously excluded from it. It had a documentary authenticity that apparently transcended partiality. Once spoken, words were protected from the worst of the censorship. It seems plausible to suppose also that stenography infused new, more colloquial elements into the written standard; at the very least, there was a new reciprocal relationship between spoken and written language. ${ }^{149}$

On the other hand, the prerogative of the powerful to influence public communications to their advantage was recast rather than fundamentally challenged. The adoption of stenography, whether in the courts of the reform era, the State Duma, or the many political assemblies of the early Soviet period, brought into the public domain a vast amount of talk which would otherwise have been inaudible. Like the Internet in our own times, this was taken by many observers as a sign of a newly democratic public sphere. But, again like the Internet, published stenographic transcripts very soon outstripped the capacity of any single person or even group of people to read and assimilate them. What 
counted was the power to control the way the words were recorded, the way they were disseminated, and the way they were remembered and cited; to exercise authority over the interpretation of the spoken word. There were always limits to the extent to which stenography empowered the population. As one of many possible examples, consider what is perhaps the greatest paradox of the medium: from the very beginning, in the 1860 s, most stenographers were women, but the vast majority of the speakers whose words they recorded were not.

\section{NOTES}

1. ${ }^{*}$ I thank the readers and editors of Cahiers du Monde russe, and Oleg Khlevniuk, for their helpful comments on this paper.

M. Ivanin, O stenografii ili iskusstve skoropisi, v primenenii ee $\mathrm{k}$ russkomu iazyku [On stenography or the art of fast writing, as applied to the Russian language] (SPb. : tipografiia Imperatorskoi Akademii nauk, 1858), 20.

2. S. Dlusskii, Chto takoe stenografiia? Znachenie ee $\mathrm{v}$ istoricheskom, obshchestvennom i pedagogicheskom otnosheniiakh [What is stenography? Its significance in the historical, social and pedagogical aspects] (SPb. : D.F. Fedorov, 1874), quotation 25.

3. Ivanin, O stenografii, 20-1.

4. Grafodromiia ili Iskusstvo skoropisi : Sochinenie g. Ast'e. Peredelannoe i primenennoe k russkomu iazyku baronom Modestom Korfom [Graphodrome or the Art of fast writing: The work of Mr Astier. Revised and applied to the Russian language by Baron Modest Korf] (SPb.: V tipografii N. Grecha, 1820).

5. Stenografiia, ili iskusstvo pisat' takzhe skoro, kak govoriat [Stenography, or the art of writing just as fast as people speak] (M. : Universitetskaia tipografiia, 1844).

6. I.I. Lazhechnikov, Sochineniia v dvukh tomakh [Works in two volumes] (M. : Gosudarstvennoe izdatel'stvo khudozhestvennoi literatury, 1963), vol. 2, 79.

7. "Vospominaniia E.A. Drashusovoi (1842-1847) [The memoirs of E.A. Drashusova (1842-1847]," in Rossiiskii arkhiv (2004) : 184.

8. P.A. Viazemskii, Staraia zapisnaia knizhka [An old notebook] (M. : Zakharov, 2003), 622-3 (entry of 30 October 1830).

9. Mikhail Gershenzon, Nikolai I i ego epokha [Nicholas I and his era] (M. : Zakharov, 2001), 82.

10. N.E. Tornau, Rech', proiznesennaia 3 ianvaria 1868 goda $\mathrm{v}$ Khar'kovskom universitete Baronom Tornau, pri otkrytii kursa stenografii I.A. Ustinovym [Speech delivered on 3 January 1868 in Khar'kov University by Baron Tornau on the opening of a course in stenography by I.A. Ustinov] (Khar'kov : Gubernskaia tipografiia, 1868), 4-5.

11. See the account of working for Artobolevskii in N.K. Mikhailovskii, "Literaturnye vospominaniia [Literary memoirs]," in idem, Literaturnaia kritika i vospominaniia [Literary criticism and memoirs ] (M. : Iskusstvo, 1995), 252-3. Another disparaging mention can be found in N.A. Ershov, Obzor russkikh stenograficheskikh sistem [Survey of Russian stenographic systems] (SPb. : red. zhurnala "Pedagogicheskii muzei"), 37.

12. For a brief discussion of stenography in the reform era, see Stephen Lovell, "Glasnost' in Practice : Public Speaking in the Era of Alexander II," Past \& Present, 218 (2013) : 132-4. 
13. Skopcheskoe delo. Protsess Kudrinykh i drugikh 24 lits, obviniaevmykh v prinadlezhnosti k skopcheskoi eresi. Stenograficheskii otchet v dvukh chastiakh [The case of the Skoptsy. The trial of the Kudrins and 24 other persons accused of belonging to the Skoptsy heresy. Stenographic report in two parts] (M. : A.P. Sokolov, 1871) ; Stenograficheskii otchet. Protsess G-zhi Dmitrievoi, polkovnika Karitskogo, st. sov. Diuzinga, vracha Sapozhkova i g-zhi Kassel' [Stenographic report. The trial of Mrs Dmitrieva, Colonel Karitskii, State Counsellor Diuzing, Doctor Sapozhkov and Mrs Kassel'] (M. : Ia.O. Bogdanov, 1871); Delo Miasnikovykh : Polnyi stenograficheskii otchet s prisovokupleniem otzyvov gazet i zhurnalov o verdikte prisiazhnykh zasedatelei [The case of the Miasnikovs : Full stenographic report with the addition of newspaper and journal responses to the jury's verdict] (SPb. : tip. M. Khana, 1872). On the Dmitrieva trial, which featured star turns from Urusov, Spasovich and Plevako, see Louise McReynolds, Murder Most Russian : True Crime and Punishment in Late Imperial Russia (Ithaca : Cornell University Press, 2013), 37-41.

14. A.M. Iurkovskii, Stenografiia skvoz' veka [Stenography through the ages] (M. : Kniga), 59.

15. Louise McReynolds, The News under Russia's Old Regime: The Development of a Mass-Circulation Press (Princeton : Princeton University Press, 1991), 60.

16. V.I. Smoliarchuk, Advokat Fedor Plevako : Ocherk o zhizni i sudebnoi deiatel'nosti advokata F.N. Plevako [The lawyer Fedor Plevako : A sketch of the life and courtroom activity of the lawyer F.N. Plevako] (Cheliabinsk : Iuzhno-Ural'skoe knizhnoe izdatel'stvo, 1989), 79.

17. For an interesting parallel case study of Russian literature's interaction with another technology of reproduction, see Stephen Hutchings, Russian Literary Culture in the Camera Age : The Word as Image (London : RoutledgeCurzon, 2004).

18. D.I. Pisarev, "Pisemskii, Turgenev i Goncharov," in idem, Sochineniia v chetyrekh tomakh [Works in four volumes] (M.: Gosudarstvennoe izdatel'stvo Khudozhestvennoi literatury, 1955-56), vol. 1, 200.

19. In his novel Obryv [The ravine] (1869), part 3, chap. 18.

20. Dostoevskii's future wife was one of the first graduates of the women's gimnaziia. With her father in poor health, she turned to stenography in 1866 as a promising career opportunity. See A.G. Dostoevskaia, Vospominaniia [Memoirs] (M. : Pravda, 1987), 50-2. For a perceptive reading of "Krotkaia" as an example of (failed) oral communication, see Gabriella Safran, "The Troubled Frame Narrative : Bad Listening in Late Imperial Russia," Russian Review, 72, 4 (2013) : 556-72.

21. V.G. Korolenko, "Multanskoe zhertvoprinoshenie [The Multan sacrifice]" (1895), in his Sobranie sochinenii v desiati tomakh [Collected works in ten volumes] (M.: Gosudarstvennoe izdatel'stvo Khudozhestvennoi literatury, 1953-56), vol. 9, 342.

22. As noted in Iurkovskii, Stenografiia, 60.

23. On Kliuchevskii's scintillating lectures and Plevako's "hypnotic" speeches, see V.A. Nelidov, Teatral'naia Moskva : Sorok let moskovskikh teatrov [Theatre-going Moscow: Forty years of Moscow theatres] (M. : Materik, 2002), 27-9, 35. On the impression made by Alekseev as both public speaker and chair of the Moscow city duma, see N.A. Varentsov, Slyshannoe. Vidennoe. Peredumannoe. Perezhitoe [What I have heard, seen, reflected on and experienced] (M. : Novoe literaturnoe obozrenie, 1999), 353-5.

24. For example: A. Ben, Stilistika i teoriia ustnoi i pis'mennoi rechi [Style and the theory of oral and written speech] (M.: K.T. Soldatenkov, 1886), a translation of Alexander Bain's English Composition and Rhetoric; M. Brodovskii, Iskusstvo ustnogo izlozheniia (chtenie vslukh, deklamatsiia, oratorskaia rech' i proch.) [The art of oral exposition (reading aloud, declamation, oratory and so on] (SPb.: G. Goppe, 1887). Advice on public speaking would becoming more professionalized and medicalized by the early twentieth century : see for example V. Larionov, Psikhologiia krasnorechiia [The psychology of eloquence] (SPb. - M. : T-vo M. O. Vol'f, 1908).

25. Sergei Muromtsev, Stat'i i rechi [Articles and speeches] (M.: tip. Obshchestva rasprostraneniia poleznykh knig, 1910), 117-19, 121-2. 
26. A.F. Pisemskii, Meshchane [The Philistines] (1877), in idem, Sobranie sochinenii v deviati tomakh [Collected works in nine volumes] (M. : Izdatel'stvo "Pravda", 1959), vol. 7, 114.

27. For a contemporary account, see V.Iu. Skalon, Zemskie voprosy: Ocherki i obozreniia [Zemstvo issues: Sketches and surveys] (M. red. gazety "Zemstvo", 1882). For modern scholarship on the subject, see for example S. Frederick Starr, Decentralization and Self-Government in Russia, 1830-1870 (Princeton : Princeton University Press, 1972), esp. chap. 5. 28. Stenograficheskii otchet zasedanii Simbirskogo gubernskogo zemskogo sobraniia sessii 1886 goda [Stenographic report of the sessions of the zemstvo assembly for Simbirsk province in 1886] (Simbirsk : Tipografiia P.V. Murakhovskogo, 1887), 21-3, 43-50.

29. S. Sharapov, "S Volgi [From the Volga]," Novoe vremia, 28 September (10 October) $1891: 1$.

30. V.A. Maklakov, Iz vospominanii [From my memoirs] (New York : Izdatel'stvo im. Chekhova, 1954), 146-8.

31. V.M. Chernov, Pered burei [Before the storm] (M. : Mezhdunarodnye otnosheniia, 1993), 92.

32. P.N. Miliukov, Vospominaniia, 1859-1917 [Memoirs, 1859-1917] (New York : Izdatel'stvo im. Chekhova, 1955), 158-9, 164-5. The lectures were delivered just after the death of Alexander III in October 1894 - a time of high expectations, which the new tsar soon tried to suppress in his notorious "idle dreams" speech of January 1895.

33. N.I. Astrov, Vospominaniia [Memoirs] (M: Gosudarstvennaia publichnaia istoricheskaia biblioteka, 2000), quotation 46.

34. Stenograficheskii otchet ocherednogo Tverskogo gubernskogo zemskogo sobraniia, sessii 1898 goda, zasedanii 8, 9, 11-16, 18-23 ianvaria $1899 \mathrm{~g}$. [Stenographic report of the latest 1898 session of the zemstvo assembly of Tver' province, the sittings of 8, 9, 11-16 and 18-23 January 1899] (Tver' : Tipografiia Tverskogo Gubernskogo Zemstva, 1899), 3-12.

35. V.A. Obolenskii, Moia zhizn', moi sovremenniki [My life, my contemporaries] (P.: YMCA-Press, 1988), 222-3.

36. Obolenskii, Moia zhizn', 266. See also Terence Emmons, "Russia's Banquet Campaign," California Slavic Studies, 10 (1977) : 45-86.

37. "Vnutrennie izvestiia [Domestic news]," Russkie vedomosti, 14 October $1904: 2$. Note also the editorial on the same subject in Russkie vedomosti, 17 October $1904: 1$.

38. Obolenskii, Moia zhizn', 272-3.

39. For the account of one participant, see Obolenskii, Moia zhizn', 276-88.

40. Astrov, Vospominaniia, 99-100, 103-6.

41. The state printing house also distributed free copies of the transcripts to public libraries around Russia : one copy per 150,000 population (according to the 1897 census), which amounted to 1500 copies of each session's transcript. N.B. Selunskaia, ed., Stanovlenie rossiiskogo parlamentarizma nachala XX veka [The making of Russian parliamentarianism at the beginning of the $20^{\text {th }}$ century] (M. : Mosgorarkhiv, 1996), 147.

42. Quotations from Gosudarstvennaia Duma: Stenograficheskie otchety. 1906 god. Sessia pervaia [The State Duma. Stenographic reports. 1906. First session] (SPb.: Gosudarstvennaia tipografiia, 1906), vol. 1, 246, 248.

43. M. Mogilianskii, Pervaia Gosudarstvennaia Duma [The first State Duma] (SPb : M.V. Pirozhkov, 1907), 57.

44. Gosudarstvennaia Duma. Vtoroi sozyv. Stenograficheskie otchety. 1907 god. Sessiia vtoraia [The State Duma. Second convocation. Stenographic reports. 1907. Second session], vol. 1 (SPb. : Gosudarstvennaia tipografiia, 1907), 140.

45. Gosudarstvennaia Duma. Vtoroi sozyv., vol. 1, 163.

46. For example, Graf Aleksis Zhasminov, "Moia sobstvennaia Duma [My very own Duma]," Novoe Vremia, 12/25 January $1907: 4$, which offered an acerbic report on the excitable oratory of the Octobrists and the Social Democrats in their electoral campaigning. 
47. V.Ger'e, Vtoraia Gosudarstvennaia Duma [The second State Duma] (M.: Pechatnia S.P. Iakovleva, 1907), 1.

48. I-v, "Tolstoi i stenografiia [Tolstoi and stenography]," Voprosy stenografii (hereafter VS), no. 8-9 (1928) : 3-4. Before Gusev arrived, Tolstoi had been dictating into a phonograph given to him by Edison.

49. S. Iudina, "Rabota stenografov v dorevoliutsionnoi Moskve [The work of stenographers in prerevolutionary Moscow]," VS, no. 3 (1927) : 4-6.

50. Earlier in 1906, under the auspices of the Ministry of Internal Affairs, a group of 18 people had been sent to receive stenographic training in Finland, which already had experience of parliamentary life. Selunskaia, ed., Stanovlenie rossiiskogo parlamentarizma, 144-5 (although no source is provided for this information).

51. Iurkovskii, Stenografiia, 62-4.

52. S. Beier, "Stenograficheskaia rabota v b. Gosudarstvennoi Dume i Gosudarstvennom Sovete [Stenographic work in the former State Duma and State Council]," VS, no. 1/3 (1924): 26-7 ; S. Beier, "O rabote stenografov v gosudarstvennoi dume i gosudarstvennom sovete [On the work of stenographers in the state duma and state council ]," VS, no. 3 (1927) : 6-9.

53. "Iz zaly Gosudarstvennoi Dumy (Po telefonu) [From the hall of the State Duma (By telephone)]," Russkie vedomosti, 4 May $1906: 3$.

54. Russkie vedomosti, 14 May $1906: 3$.

55. "Zasedanie 3-go maia [The sitting of 3 May]," Russkie vedomosti, 4 May $1907: 3$.

56. "Zasedanie 20-go noiabria [The sitting of 20 November]," Russkie vedomosti, 21 November $1907: 3$.

57. Other such interventions came on 7 March and 13 March. See Gosudarstvennaia Duma. Vtoroi sozyv, vol. 1, 134, 218, 483, 511. For an example from the Third Duma (13 November 1907), see Gosudarstvennaia Duma. Tretii sozyv. Stenograficheskie otchety. 1907-1908 gg. Sessiia pervaia. Chast' I [The State Duma. Third convocation. Stenographic reports. 1907-1908. First Session. Part 1] (St Petersburg : Gosudarstvennaia tipografiia, 1908), 165.

58. Gosudarstvennyi Sovet: Stenograficheskie otchety: 1906 god: Sessiia pervaia [The State Council : Stenographic reports : 1906 : First session] (SPb. : Gosudarstvennaia tipografiia, 1906).

59. Gosudarstvennaia Duma. Chetvertyi sozyv. Stenograficheskie otchety. 1914 g. Sessiia vtoraia. Chast' II [The State Duma. Fourth convocation. Stenographic reports. 1914. Second session. Part 2] (SPb. : Gosudarstvennaia tipografiia, 1914), 222-4.

60. Gosudarstvennyi sovet : Stenograficheskie otchety : 1906 god, sitting of 6 July 1906, 11-15.

61. Gosudarstvennaia Duma. Vtoroi sozyv. Stenograficheskie otchety. 1907 god. Sessiia vtoraia, vol. 1, 676-7.

62. Gosudarstvennyi sovet : Stenograficheskie otchety : 1906 god, sitting of 6 July, 15-16 ; sitting of 7 July, 1-2.

63. Astrov, Vospominaniia, 166.

64. P. Larev, "Nasushchnaia potrebnost' [An essential need]," Golos i rech', no. 4 (1913) : 23-4.

65. Obolenskii, Moia zhizn', 352, 359-62, 380. For characterizations of Duma speakers, see also Mogilianskii, Pervaia Gosudarstvennaia Duma.

66. A skeptical view on both Muromtsev and Plevako was taken by the eminent lawyer Nikolai Karabchevskii in his Chto glaza moi videli [What I saw with my own eyes] (Berlin : Izdanie Ol'gi D 'iakovoi, 1921), 13-14.

67. On tongue-tied contributions from peasant deputies, see Obolenskii, Moia zhizn', 357-8.

68. Gosudarstvennyi Sovet : Stenograficheskie otchety. 1906 god. Sessiia pervaia, 8.

69. Gosudarstvennaia Duma. Vtoroi sozyv, vol.1, 2285-7. On the outraged response in government circles to Zurabov's speech, which almost brought the closure of the Duma there and then, as well as the indignation on the Left at the chairman's actions, see Alfred Levin, The Second Duma : A Study of the Social Democratic Party and the Russian Constitutional Experiment 
(New Haven: Yale University Press, 1940), 294-305, and Abraham Ascher, P.A. Stolypin: The Search for Stability in Late Imperial Russia (Stanford : Stanford University Press, 2001), 191-3.

70. The Bolsheviks used the immunity of Duma transcripts from censorship in order to publish their programme in Pravda; in the chamber they met a predictably hostile reception. See A. Badayev, The Bolsheviks in the Tsarist Duma (London : M. Lawrence, 1932), 44, 52-3.

71. The claim of objectivity was made by a deputy from Tomsk named Nekrasov. The same position was argued by Kerenskii, while Vasilii Maklakov (the representative of the drafting commission) objected on the grounds that this was hardly the business of the Nakaz. Gosudarstvennaia Duma. Chetvertyi sozyv. Stenograficheskie otchety. 1914 g. Sessiia vtoraia. Chast' II [State Duma. Fourth convocation. Stenographic reports. 1914. Second session. Part 2] (SPb. : Gosudarstvennaia tipografiia, 1914), 257-9.

72. For confirmation of the point from three different places on the political spectrum, see: A.G. Shliapnikov, Kanun semnadtsatogo goda. Semnadtsatyi god [The eve of 1917. The year 1917], vol. 1 (M. : Izdatel'stvo politicheskoi literatury, 1992), 283 ; M.V. Rodzianko, Krushenie imperii [The fall of an empire ] (M. : Skify, 1992), 194 ; and V.V. Shul'gin, Gody. Dni. 1920 god [Years. Days. The year 1920] (M. : Novosti, 1990), 373.

73. Gosudarstvennaia Duma, Chetvertyi sozyv, sessiia V: Stenograficheskii otchet [The State Duma. Fourth convocation, session 5 : Stenographic report] (Pg. : Gosudarstvennaia tipografiia, 1917), 167, 173-4, 1245.

74. Gosudarstvennaia Duma, Chetvertyi sozyv, sessiia V, 241.

75. A.A. Oznobishin, Vospominaniia chlena IV-i Gosudarstvennoi dumy [Memoirs of a member of the fourth State Duma] (P. : Izd. E. Sial'skoi, 1927), 207-8.

76. Gosudarstvennaia Duma, Chetvertyi sozyv, sessiia V, 1243.

77. Georgii Chicherin, "Privetstvie zhurnalu 'Voprosy stenografii' [A greeting to the journal Voprosy stenografii]," VS, no. 1 (1923) : 25.

78. L. Fotieva, "O rabote stenografov v Sovete Narodnykh Komissarov i v Sovete Truda i Oborony [On the work of stenographers in the Council of People's Commissars and the Council of Labour and Defence]," VS, no. 1 (1924) : 7-8.

79. Iurkovskii, Stenografiia, 65-7, 69.

80. S. Iudina, "Rabota stenografov v Sovetskoi Rossii [The work of stenographers in Soviet Russia ]," VS, no. 1 (1923) : 2-7.

81. S. Iudina, "Vospominaniia : Stranichki proshlogo [Memoirs : Pages from the past]," VS, no. 11 (1927) : 6-9.

82. Iudina, "Rabota stenografov," 5.

83. Iudina, "Rabota stenografov," 6-7; R. Veksman, "Vospominanie o Vladimire Il'iche [Remembering Vladimir Il'ich]," VS, no. 1 (1924) : 4 ; V. Ostroumova, "Lenin, kak orator s tochki zreniia stenografa [Lenin as an orator from the stenographer's point of view]," VS, no. 1 (1924) : 5-6.

84. Chicherin, "Privetstvie zhurnalu 'Voprosy stenografii," 24.

85. Quotations from "Mysli obshchestvennykh i politicheskikh deiatelei Sovetskoi Rossii o stenografii [Thoughts about stenography by prominent social and political figures in Soviet Russia]," VS, no. 2 (1923) : 1-4.

86. GARF (Gosudarstvennyi arkhiv Rossiiskoi Federatsii), f. 5468 (Tsentral'nyi komitet professional'nogo soiuza sovetskikh i torgovykh sluzhashchikh), op. 3, d. 127.

87. GARF, f. 5468, op. 4, d. 173.

88. GARF, f. 5468 , op. 7, d. $352,1.2$.

89. See the transcript of the conference at GARF, f. 5468, op. 8, d. 343, 1. 7, 16, 18.

90. R. Veksman, "Stenografiia za 5 let [Five years of stenography]," Voprosy stenografii i mashinopisi, no. 5-6 (1930) : 4 . 
91. N.I. Iakusheva, Vospominaniia s"ezdovskoi stenografistki, 1930-1938 [Memoirs of a congress stenographer, 1930-1938] (M. : MSKhA, 2003).

92. The delegate was A. Iurkovskii (b. 1901), later the author of a standard Soviet survey of the history of stenography in Russia. In his account of the trip he remarked that champagne and dancing allowed little time for serious work: GARF, f. 5468, op. 10, d. 528.

93. V. Ostroumova, "My i Oni [Us and them]," VS, no. 2 (1924) : 3-6.

94. The idea of making stenography a compulsory subject was, for example, put forward by some speakers at a meeting of various agencies to discuss training of stenographers in September 1924 : see GARF, f. 5468, op. 7, d. 352.

95. VS, no. 1 (1923) : 1-2.

96. As remarked by a speaker at the first stenographers' conference : GARF, f. 5468, op. 8, d. 343, 1. 207.

97. L. Trotskii, “O stenografii,” VS, no. 3 (1924) : 2.

98. The "tourist" jibe was used by a stenographer from Yaroslavl at the first stenographers' conference: GARF, f. 5468, op. 8, d. 343, 1.224. In the mid-1920s, different rates of pay were recommended for four distinct categories of stenographer, ranging from "congress" stenographers capable of taking down more than 110 words per minute to secretarial stenographers who managed 75 words per minute. See GARF, f. 5468, op. 8, d. 354, 1.1-2 (correspondence between the stenographers' union and the central trade union organization and the ministry of labour, 1925).

99. This is the language used in a protest letter from a congress stenographer in Tiflis in 1928, GARF, f. 5468, op. 11, d. 500, 1. 30.

100. For these and several other examples, see GARF, f. 5468, op. 8, d. 358.

101. The questions of differential pay for stenographers of different levels of facility and of fair work norms for stenographers were raised by R. Veksman at the first stenographers' conference : GARF, f. 5468, op. 8, d. 343, 1. 166-74.

102. On the attitude of employers, see S. Iudina, "Stenografy v uchrezhdeniiakh [Stenographers in institutions]," Voprosy stenografii i mashinopisi, no. 6 (1928) : 4-6.

103. Beier, "O rabote stenografov v gosudarstvennoi dume i gosudarstvennom sovete," 6-9.

104. GARF, f. 5468, op. 7, d. 352, 1. 25.

105. GARF, f. 5468, op. 8, d. $343,1.19$.

106. GARF, f. 5468, op. 8, d. 343, 1. 129.

107. Veksman, "Stenografiia za 5 let," 5.

108. GARF, f. 5468 , op. 8 , d. $343,1.54$.

109. "K novym zadacham [On our new tasks]," Voprosy stenografii i mashinopisi, no. 2 (1928) : 1-2.

110. Japan is an interesting comparative case. In the Imperial Diet (established in 1890) speeches were recorded by stenographers as they later would be in Russia's State Duma. Initially, while this kind of political eloquence retained its novelty value, stenography was a prestigious and well-paid activity that was performed by men. In the early twentieth century, however, it came to be seen instead as a labour of "repetition and reproduction," and the profession was accordingly feminized. See Miyako Inoue, "Stenography and Ventriloquism in Late Nineteenth Century Japan," Language \& Communication, 31 (2011) : 181-2.

111. GARF, f. 5468, op. 7, d. $352,1.15$.

112. Witness the discussion "Nauka ili iskusstvo [Science or art]," VS, no. 4 (1926) : 5-6.

113. GARF, f. 5468, op. 8, d. 343, 1. 41.

114. Ne-avtomat, "Stenograf-avtomat i problema unitarnoi [The automated stenographer and the problem of a unified system]," VS, no. 7 (1926) : 20-1.

115. Cost estimates from B. Vishnevskii, "Itogi po voprosu o stenografe-avtomate [Conclusions on the question of the automated stenographer]," VS, no. 3 (1927) : 24-5. Note also B. Vishnevskii, 
"Stenograf-avtomat prof. Kovalenkova [The automated stenographer of Professor Kovalenkov]" and Redaktsiia, "K izobreteniiu prof. Kovalenkova [On the invention of Professor Kovalenkov]," VS, no. 1 (1927) : 16-17.

116. GARF, f. 5468, op. 11, d. 500, 1. 135.

117. For one statement of the predicament, see A. Egorov (Simferopol'), "Melochi nashei zhizni (Vmesto fel'etona) [The minor details of our life (Instead of a feuilleton)]," VS, no. 1 (1927) : 21.

118. "Kak rasshifrovyvat' stenogrammu [How to decipher a stenogram]," VS, no. 1 (1925) : 35-6.

119. P.G. Kuvyrkin, “O redaktirovanii [On editing ]," VS, no. 5-6 (1926) : 24-5.

120. "Rechi predstavitelei TsIKa, TsK Partii, TsK Soiuza Sovtorgsluzhashchikh i NKRKI na I-oi Vsesoiuznoi konferentsii [The speeches of representatives of the Central Executive Committee, the Central Committee of the Party, The Central Committee of the Union of Soviet Trade Workers and the Peasant-Worker Inspectorate at the First All-Union Conference]," VS, no. 2 (1925) : 5.

121. M. Kholodenko i M. Sichikov, "Stenograficheskii protokol [Stenographic minutes]," VS, no. 1 (1927) : 13-15.

122. O. Chebkasova, "O stenograficheskom protokole (V poriadke obsuzhdeniia) [On stenographic minutes (For the purposes of discussion)]" and N.P., "Ot slov k delu [From words to action]," in Voprosy stenografii i mashinopisi, no. 2 (1929) : 7-8.

123. A point made in Iu. Shcheglova, "Eshche o redaktirovanii [Once again on editing]," VS, no. 2 (1927) : 13.

124. N. Faleev, “Aforizmy o stenografii [Aphorisms on stenography]," VS, no. 2 (1924) : 28.

125. A.Iu. Vatlin et al. (eds), Stenogrammy zasedanii Politbiuro TsK RKP(b)-VKP(b). 1923-1938 gg. [Stenograms of the meetings of the Politburo of the Central Committee of the Russian/All-Union Communist Party, 1923-1938] 3 vols (M.: ROSSPEN, 2007), introduction to vol. 1, 7-18, quotation 11. For more on the use made of these documents, see Paul R. Gregory and Norman Naimark, The Lost Politburo Transcripts : From Collective Rule to Stalin's Dictatorship (New Haven : Yale University Press, 2008), especially the chapters by Paul Gregory, Robert Service and Leona Toker. On measures of secrecy, see O.V. Khlevniuk et al., eds., Stalinskoe Politbiuro v 30-e gody : Sbornik dokumentov [Stalin's Politburo in the 1930s: A collection of documents] (M. : “AIRO - XX”, 1995), 73-82.

126. V.P. Danilov, O.V. Khlevniuk and A.Iu. Vatlin, eds., Kak lomali NEP. Stenogrammy plenumov TsK VKP(b) 1928-1929 gg. [How NEP was broken. Stenograms of the plenums of the Central Committee of the All-Union Communist Party, 1928-1929], 5 vols (M.: Mezhdu-narodnyi fond "Demokratiia", 2000) (hereafter Kak lomali NEP), vol. 2, 513.

127. Kak lomali NEP, vol. 1, 12-13.

128. For these two examples, compare Kak lomali NEP, vol. 2, 149-56 with vol. 2, 612-21 and vol. 2, 353-69 with vol. 2, 625-44.

129. See especially ibid., vol. 2, 390-2, 404-5.

130. Kak lomali NEP, vol. 2, 153 (for the other two examples, see vol. 2, 358, 514). In the uncorrected stenogram, Stalin's reply read more apologetically: “Tem luchshe, znachit ia ne tak slyshal, plokho slyshal" (vol. 2, 617). Here is another example of how even minor editorial changes served to bolster Stalin's authority.

131. Kak lomali NEP, vol. 2, 455. For similar examples from the following plenum, see $3: 395,402$.

132. Kak lomali NEP, vol. 2, 520.

133. Examples in this paragraph from Kak lomali NEP, vol. 2, 460-1, 519, vol. $3,403$.

134. Kak lomali NEP, vol. 3 , 250. Earlier that year, Frumkin had sent a letter to the Politburo criticizing its policy on the peasants.

135. Kak lomali NEP, vol. 3, 276.

136. Lev Trotskii was also well aware of the possibility that phrases from a stenogram might be quoted out of context. In correcting the transcript of his speech to the $15^{\text {th }}$ Party Conference (the last occasion that he and other leading "Leftists" would be offered such a platform), he insisted 
on adjusting a phrase that might easily be taken to suggest that he saw the USSR as a "non-proletarian state": daleko ne-proletarskogo gosudarstva [far from proletarian state] became daleko ne-chisto proletarskogo gosudarstva [far from purely proletarian state]. See RGASPI, f. 55 (XV Vsesoiuznaia konferentsiia VKP(b)), op. 1, d. 78, 1. 2-3.

137. Kak lomali NEP, vol. 4, 151. Bukharin was also aware of the significance of the stenogram for shaping subsequent impressions of the plenum. When returning the corrected text of his own speech, he noted that some of the hostile interruptions had been amended in the process of editing, and asked to be consulted if any further such changes were made. Ibid., 710, n. 152.

138. V.P. Danilov, A.Iu. Vatlin and O.V. Khlevniuk, "Aprel'skii plenum TsK i TsKK VKP(b) 1929 g.," in Kak lomali NEP, vol. 4, 5, 14-15.

139. These documents are published in Kak lomali NEP, vol. 4, 558-63 and 5: 598-619 respectively.

140. Jürgen Habermas, The Structural Transformation of the Public Sphere (Cambridge : Polity, 1989), xviii.

141. Natalia Skradol, "Laughing with Comrade Stalin: An Analysis of Laughter in a Soviet Newspaper Report," Russian Review, 68, 1 (2009) : 27-8.

142. See Lorenz Erren, "Selbstkritik" und Schuldbekenntnis : Kommunikation und Herrschaft unter Stalin (1917-1953) (Munich : Oldenbourg, 2008).

143. On the conduct of the trial and the preparation of its transcript, see the editors' introduction in Zh.V. Artamonova and N.V. Petrov, eds., Protsess Bukharina. 1938 g. : Sbornik dokumentov [The trial of Bukharin. 1938: A collection of documents] (M. : MFD, 2013). On the extent and nature of Stalin's editorial interventions, see Iu.G. Murin (with afterword by A.M. Larina), "Kak fal'sifitsirovalos' 'delo Bukharina,' [How the 'Bukharin case' was falsified]," Novaia i noveishaia istoriia, 1 (1995): 61-76. Among the excisions was Bukharin's baffling pseudo-confession : "Priznaiu otvetstvennost' dazhe za te prestupleniia, o kotorykh ia ne znal i o kotorykh ne imel ni maleishego predstavleniia [I accept responsibility even for those crimes about which I did not know and of which I had not the slightest notion]."

144. A.F. Koni, Sobranie sochinenii [Collected works] (M. : Iuridicheskaia literatura, 1966-69), vol. 1, 338-9.

145. Chernov, Pered burei, 354.

146. Although Soviet Russia did from 1929 have a method of sound recording onto tape, it was used only to a very limited extent in the prewar era.

147. To my knowledge, the only attempt so far to apply Habermas's "plebiscitary-acclamatory" model of public sphere to the early Soviet case is Stuart Finkel, On the Ideological Front: The Russian Intelligentsia and the Making of the Soviet Public Sphere (New Haven : Yale University Press, 2007), 12. Finkel shows convincingly the extent of the regimentation that had occurred by late 1922. But there was still some way to go to the discursive hostage-taking of the Stalin era.

148. For useful reflections in this vein, see Gábor T. Rittersporn, Malte Rolf and Jan C. Behrends, "Open Spaces and Public Realm : Thoughts on the Public Sphere in Soviet-Type Systems," in the same authors' edited volume Sphären von Öffentlichkeit in Gesellschaften sowjetischen Typs : Zwischen partei-staatlicher Selbstinszeniurung und kirchlichen Gegenwelten (Frankfurt am Main: Peter Lang, 2003), 423-52. This book makes a good case for adapting and extending Habermas's typology to state socialist societies, while also sketching out some significant rhetorical shifts that occurred over the Soviet period.

149. This seems to have been the case in Japan after it introduced stenography in 1882 : see M. Tomasi, "Oratory in Meiji and Taisho Japan : Public Speaking and the Formation of a New Written Language," Monumenta Nipponica, 57 (2002) : 59. 


\section{ABSTRACTS}

Stenography brought about an unsung revolution in the modern world: for the first time ever, writing could keep up with speech*. In Russia, the adoption of this technology came later than in France or Britain, but it was concentrated in time and tied to a particular civilizational project: the Great Reforms launched in the 1860s, with their key values of glasnost' and publichnost'. Over the decades that followed, stenography would play an important role in helping Russian society to imagine itself. Even if the right to publish was contested, stenography would also change the stakes and possibilities of political discourse. With the exhaustively recorded debates in the State Duma, stenography entered a Golden Age, which continued into the revolutionary and early Soviet periods. With the mushrooming of Soviet institutions and forms of assembly, the demands for stenographers' services had never been greater. From the mid-1920s onwards, stenography once again became contested territory, as the question of who got to control the transcript became paramount. Yet, even with the tightening of the representational system known as Socialist Realism, stenography retained-at least until the adoption of user-friendly sound recording technology in the mid-1940s-much of its significance as a documentary record of public speech.

La sténographie est à l'origine d'une révolution méconnue dans le monde moderne: pour la première fois, l'écriture pouvait suivre la parole. En Russie, l'adoption de cette technique intervint plus tard qu'en France ou en Angleterre mais elle fut concentrée dans le temps et en lien avec un projet de civilisation particulier, à savoir, dans les années 1860, le lancement des Grandes Réformes, basées sur les valeurs fondamentales de la transparence (glasnost') et de la publicité (publičnost'). Au cours des décennies qui suivirent, la sténographie contribua fortement à aider la société russe à se penser. Même si le droit de publier était contesté, la sténographie changea les enjeux et les possibilités du discours politique. Avec la retranscription exhaustive des débats à la Douma, la sténographie entra dans un Âge d'or qui se maintint pendant la période révolutionnaire jusqu'au tout début de l'ère soviétique. Avec la prolifération des institutions et diverses assemblées soviétiques, la demande en sténographes n'avait jamais été aussi grande. À partir du milieu des années 1920, la sténographie fut de nouveau contestée : la question de savoir qui détenait le contrôle de la transcription devenait primordiale. Cependant, même avec le durcissement du système de représentation connu sous le nom de réalisme socialiste, la sténographie conserva beaucoup de son importance en tant que moyen permettant l'enregistrement documentaire de discours publics, du moins jusqu'à l'adoption, dans le milieu des années 1940, d'appareils d'enregistrement du son faciles d'emploi.

\section{AUTHOR}

\section{STEPHEN LOVELL}

Department of History, King's College London, stephen.lovell@kcl.ac.uk 